\title{
Acceptance Model of a Mandatory Health Information System in Indonesia
}

\author{
Heru Santoso Wahito Nugroho ${ }^{1}$, Hari Basuki Notobroto ${ }^{2}$, Lilin Rosyanti ${ }^{3}$ \\ 'Department of Midwifery, Poltekkes Kemenkes Surabaya, Surabaya, Indonesia \\ ${ }^{2}$ Faculty of Public Health, Universitas Airlangga, Surabaya, Indonesia \\ ${ }^{3}$ Department of Nursing, Poltekkes Kemenkes Kendari, Kendari, Indonesia
}

Objectives: The purpose of this study was to develop a model of acceptance of the Mother and Child Health Information System in the Ngawi Regency Health Office, Indonesia based on the technology acceptance model, by integrating organizational support and personal characteristics as external variables and enjoyment as an intervening variable. Methods: The design of this study was cross-sectional. The subjects of this study were 217 village midwives who had operated the Maternal and Child Health Information System in the Ngawi Regency Health Office, Indonesia. The variables studied were perceived organizational support, personal characteristics, perceived ease of use, perceived usefulness, perceived enjoyment, behavioral intention, and actual system use. Data were collected through questionnaires, and then analyzed using structural equation modeling. Results: In terms of the total effect, the most meaningful factor affecting actual system use was perceived organizational support (0.766), followed in descending order by behavioral intention to use (0.344), perceived enjoyment $(0.238)$, personal characteristics (0.118), perceived usefulness (0.054), and perceived ease of use (0.048). Conclusions: In the acceptance model of the Mother and Child Health Information System in Ngawi Regency, perceived organizational support was the main determinant of actual system use, while enjoyment was the main intermediate determinant of the indirect effects of perceived organizational support and personal characteristics on actual system use.

Keywords: Health Information System, Electronic Health Records, Health Services, Maternal-Child Health Services, CrossSectional Studies

Submitted: March 29, 2020

Revised: 1st, January 31, 2021; 2nd, March 24, 2021

Accepted: March 24, 2021

\section{Corresponding Author}

Heru Santoso Wahito Nugroho

Department of Midwifery, Poltekkes Kemenkes Surabaya, JI. Pucang Jajar Tengah 56, Surabaya, Jawa Timur 60282, Indonesia. Tel: +6282142259360, E-mail: heruswn@poltekkesdepkes-sby.ac.id (https://orcid.org/0000-0002-4511-8307)

This is an Open Access article distributed under the terms of the Creative Commons Attribution Non-Commercial License (http://creativecommons.org/licenses/bync/4.0/) which permits unrestricted non-commercial use, distribution, and reproduction in any medium, provided the original work is properly cited.

(C) 2021 The Korean Society of Medical Informatics

\section{Introduction}

Maternal and child health $(\mathrm{MCH})$ deserves special attention because mothers and children are classified as vulnerable groups experiencing health problems. In Indonesia, one of the efforts to increase the success of $\mathrm{MCH}$ programs is through monitoring program coverage on an ongoing basis. At the beginning of their implementation, all regencies (a sub-provincial administrative unit) and cities carried out these programs routinely, but the subsequent reach and quality of $\mathrm{MCH}$ services have not yet resulted in a decrease in the maternal mortality rate and infant mortality rate [1]. For this reason, a strong health information system is needed, with the ability to support the efforts of health institutions [2] by 
providing information accurately, promptly, and in accordance with the need to support decision-making [3].

The Ngawi Regency Health Office has long implemented an $\mathrm{MCH}$ information system involving all village midwives in Ngawi Regency as end users, because no specialized operating staff are available. At the beginning of its implementation, this system ran well, but recently there has been a decline in system implementation. The health information system assessor team reported that only $32.72 \%$ of midwives were still involved with the MCH Information System [4]. This condition shows "the low use of the $\mathrm{MCH}$ Information System by users."

According to the technology acceptance model (TAM), the user acceptance of information technology is characterized by the act of using information technology, known as actual system use [5-7]. Thus, the low use of the $\mathrm{MCH}$ Information System indicates that the level of actual system use in the system is still low. Furthermore, actual system use is influenced by intention or voluntary willingness to use information technology, known as behavioral intention to use. Behavioral intention to use is influenced by the perceived ease of use of information technology, and perceived usefulness, which refers to the benefit gained by users of the relevant information technology [5-7].

In 2016, a preliminary study was conducted on the causes of the low actual system use through in-depth interviews with users, and online discussions with the managers of the health information system, and five factors were found: (1) high difficulty when operating the information system; (2) low usability of the information system, which is felt by the user; (3) low intention to operate the information system; (4) low enjoyment when operating the information system; and (5) lack of organizational support.

Referring to TAM [5-7], the level of difficulty relates to perceived ease of use, usefulness is relevant to perceived usefulness, intention is relevant to behavioral intention to use, and enjoyment is relevant to perceived enjoyment. Organizational support is not part of the TAM, so it must be interpreted in light of another theory, organizational support theory [8], and is hereinafter referred to as perceived organizational support.

The five factors above can then be used as a basis for developing a TAM analysis of this phenomenon, by integrating personal characteristics (age, years of service, education and training, and experience using a computer).

Thus, the purpose of this study was to develop a model of acceptance of MCH Information Systems in Ngawi Regency, Indonesia based on TAM, by integrating organizational sup- port and personal characteristics as external variables, and enjoyment as an intervening variable. In general, the health information system is a mandatory system, which users are required to engage with, either voluntarily or not. Accordingly, the findings of this study will then be introduced as the Acceptance Model of the Mandatory Health Information System (AMoMHIS).

\section{Methods}

\section{Type, Design, Time, and Place of Research}

This research is an observational study, which was conducted with a cross-sectional design. The research was conducted in the working area of the Ngawi Regency Health Office, East Java Province, Indonesia, in 2016.

\section{Sampling Design}

The population of this study was all village midwives who were administratively assigned to the Ngawi Regency Health Office in 2016, and had participated in operating the $\mathrm{MCH}$ Information System $(\mathrm{n}=217)$. This study applied total population sampling; in other words, all village midwives were involved as research subjects. The characteristics of the village midwives were: (1) age, 25 to 55 years; (2) work period, 5 to 32 years; (3) education, diploma I to master; and (4) experience using computers, 3 to 13 years.

\section{Research Variables}

In order to build the AMoMHIS, several variables were selected, which were further divided into three groups, namely: (1) independent variables, consisting of perceived organizational support and personal characteristics; (2) intervening variables, consisting of perceived ease of use, perceived usefulness, perceived enjoyment, and behavioral intention to use; and (3) the dependent variable, namely actual system use. A schematic showing the framework of the relationships among the three groups of variables is shown in Figure 1. Based on this framework, in brief, the following five research hypotheses were generated:

1) Perceived organizational support and personal characteristics have an effect on perceived ease of use;

2) Perceived organizational support, personal characteristics, and perceived ease of use have an effect on perceived usefulness;

3) Perceived organizational support, personal characteristics, perceived ease of use, and perceived usefulness have an effect on perceived enjoyment;

4) Perceived organizational support, personal characteris- 


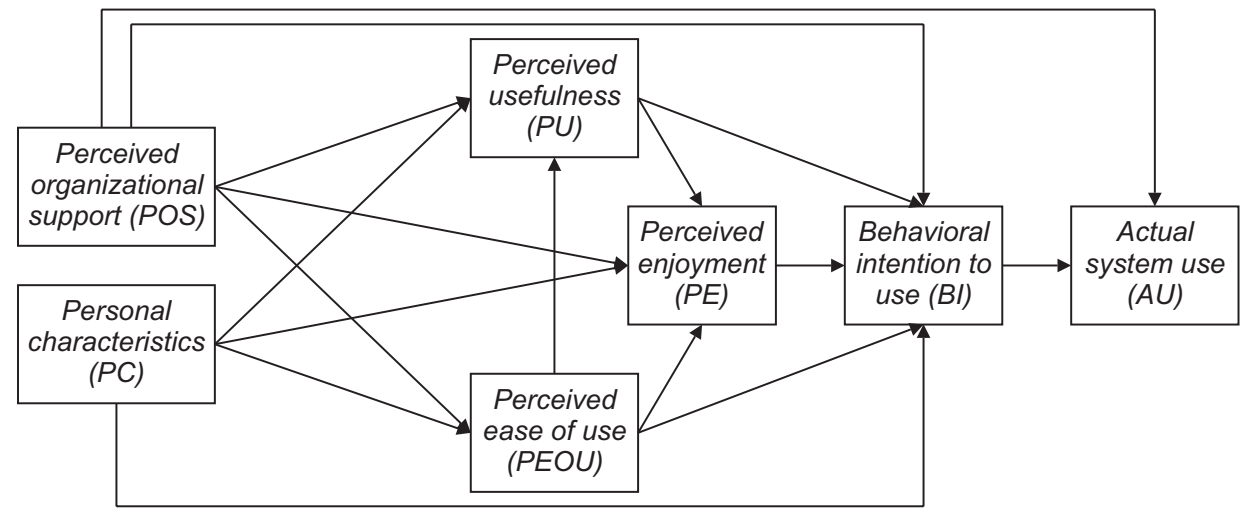

Figure 1. The relationship framework between variables.

tics, perceived ease of use, perceived usefulness, and perceived enjoyment have an effect on behavioral intention to use;

5) Perceived organizational support and behavioral intention to use have an effect on actual system use.

\section{Data Collection}

All variables were measured using questionnaires. For personal characteristics, the items were open questions. Meanwhile, information on the other six variables was gathered using closed questions in the form of semantic differentials in the range 1-10. All semantic differential items had passed a validity and reliability test which involved 30 midwives who served in the Magetan Regency Health Office, who were chosen because they had almost the same characteristics as the subjects of this study. More specifically, the questionnaires contained the following content for measuring the seven variables:

1) The personal characteristics questionnaire included four indicators: years of service, age, education and training, and computer experience;

2) The perceived organizational support questionnaire included three indicators: supervisor support, work conditions, and reward;

3) The perceived ease of use questionnaire included four indicators: system complexity, system flexibility, the ease of remembering procedures, and the amount of effort to operate the system;

4) The perceived usefulness questionnaire included four indicators: quality of work, speed of task completion, the volume of work completed, and completion of critical aspects of the work;

5) The perceived enjoyment questionnaire included three indicators: passion of operating the system, pleasure of operating the system, and adaptability to the system;

6) The behavioral intention to use questionnaire included three indicators: enthusiasm using the system, persua- siveness of using the system, and willingness to operate the system;

7) The actual system use questionnaire included three indicators: immediate operation of the system, regularity of operating the system, and sustainability of operating the system.

The stages of data collection were:

1) The researchers received an ethical clearance certificate from the Health Research Ethics Committee, Faculty of Public Health, Universitas Airlangga on May 18, 2015 (No. 272/KEPK).

2) The researchers obtained a research permit from the local government (Ngawi Regency, Indonesia).

3) The researchers organized trained enumerators (15 lecturers from the Midwifery Department, Poltekkes Kemenkes Surabaya). These enumerators were trained on January 2, 2016; in order to homogenize the data collection process, so that the possibility of bias could be minimized.

4) The researchers and enumerators facilitated the signing of informed consent and filling out questionnaires. The process of filling out the questionnaire was successfully completed in 5 days, from January 4 to 8, 2016 in all community health centers in Ngawi Regency. In order to minimize bias during the questionnaire filling process, enumerators explained in detail the objectives and procedures of the study to the respondents, and were always available to provide assistance if they encountered difficulties.

\section{Data Processing and Analysis}

All data were edited to ensure their accuracy and completeness, and confirmatory factor analysis was then conducted of the measurement model to ensure that all indicators of each construct were valid and reliable. Finally, an analysis of structural models was carried out using structural equation modeling to test the meaningfulness of all paths of 
influence between constructs, using SPSS AMOS version 19 (IBM Corp., Armonk, NY, USA). It should be noted that in the study the data were obtained from all members of the population, so that an analysis of goodness of fit was not conducted and p-values were not calculated.

\section{Results}

\section{Measurement Model}

Table 1 displays the results of confirmatory factor analysis consisting of the results of the multivariate construct normality test (the critical ratio), the validity test results for each indicator (factor loading), and the results of the construct reliability test (average variance extracted and construct reliability). The critical ratios of all constructs were $<1.96$; so that all indicators showed a normal multivariate distribution.
The factor loading of all indicators was $>0.600$, so all indicators were valid. The average variance extracted and construct reliability of all constructs were, respectively, $>0.500$ and $>0.700$; thus, all indicators were reliable.

\section{Structural Model}

After several stages of analysis, the final structural model shown in Figure 2 and Table 2 was obtained. All structural coefficients were $>0.05$ (meaningful). A description of the path of influence between variables in the structural model-including direct effects, indirect effects, and total effects-is shown in Table 3. In terms of the total effect, the most meaningful factor affecting actual system use was perceived organizational support, with a path coefficient of 0.766 , followed in descending order by behavioral intention to use, with a path coefficient of 0.344 ; perceived enjoyment,

Table 1. Summary of the results of the confirmatory factor analysis for each construct

\begin{tabular}{|c|c|c|c|c|c|c|c|c|}
\hline \multirow[b]{2}{*}{ Constructs } & \multirow[b]{2}{*}{ Indicators } & \multicolumn{2}{|c|}{ Normality test } & \multicolumn{2}{|c|}{ Validity test } & \multicolumn{3}{|c|}{ Reliability test } \\
\hline & & $\begin{array}{c}\text { Critical } \\
\text { ratio }\end{array}$ & $\begin{array}{l}\text { Interpre- } \\
\text { tation }\end{array}$ & $\lambda$ & $\begin{array}{l}\text { Interpre- } \\
\text { tation }\end{array}$ & AVE & CR & $\begin{array}{l}\text { Interpre- } \\
\text { tation }\end{array}$ \\
\hline \multirow{4}{*}{$\begin{array}{l}\text { Personal } \\
\text { characteristics }\end{array}$} & Years of service & 1.574 & Normal & 0.972 & Valid & 0.831 & 0.951 & Reliable \\
\hline & Age & & & 0.936 & Valid & & & \\
\hline & Education and training & & & 0.866 & Valid & & & \\
\hline & Computer experience & & & 0.867 & Valid & & & \\
\hline \multirow{3}{*}{$\begin{array}{l}\text { Perceived } \\
\text { organizational } \\
\text { support }\end{array}$} & Supervisor support & -0.277 & Normal & 0.815 & Valid & 0.704 & 0.877 & Reliable \\
\hline & Work conditions & & & 0.796 & Valid & & & \\
\hline & Reward & & & 0.902 & Valid & & & \\
\hline \multirow{4}{*}{$\begin{array}{l}\text { Perceived ease } \\
\text { of use }\end{array}$} & System complexity & 0.268 & Normal & 0.665 & Valid & 0.585 & 0.849 & Reliable \\
\hline & System flexibility & & & 0.797 & Valid & & & \\
\hline & Ease of remembering procedures & & & 0.834 & Valid & & & \\
\hline & The amount of effort to operate the system & & & 0.754 & Valid & & & \\
\hline \multirow{4}{*}{$\begin{array}{l}\text { Perceived } \\
\text { usefulness }\end{array}$} & Quality of work & -0.968 & Normal & 0.890 & Valid & 0.806 & 0.943 & Reliable \\
\hline & Speed of task completion & & & 0.891 & Valid & & & \\
\hline & The volume of work completed & & & 0.936 & Valid & & & \\
\hline & Completion of critical aspects of the work & & & 0.873 & Valid & & & \\
\hline \multirow{3}{*}{$\begin{array}{l}\text { Perceived } \\
\text { enjoyment }\end{array}$} & Passion for operating the system & -0.005 & Normal & 0.892 & Valid & 0.681 & 0.865 & Reliable \\
\hline & Pleasure of operating the system & & & 0.787 & Valid & & & \\
\hline & Adaptability to the system & & & 0.793 & Valid & & & \\
\hline \multirow{3}{*}{$\begin{array}{l}\text { Behavioral } \\
\text { intention to use }\end{array}$} & Enthusiasm in using the system & -0.963 & Normal & 0.811 & Valid & 0.765 & 0.906 & Reliable \\
\hline & Persuasiveness in using the system & & & 0.970 & Valid & & & \\
\hline & Willingness in running the system & & & 0.834 & Valid & & & \\
\hline \multirow{3}{*}{$\begin{array}{l}\text { Actual system } \\
\text { use }\end{array}$} & Immediate operation of the system & 0.342 & Normal & 0.900 & Valid & 0.870 & 0.953 & Reliable \\
\hline & Regularity of operating the system & & & 0.973 & Valid & & & \\
\hline & Sustainability of operating the system & & & 0.924 & Valid & & & \\
\hline
\end{tabular}

AVE: average variance extracted, CR: construct reliability, $\lambda$ : factor loading. 


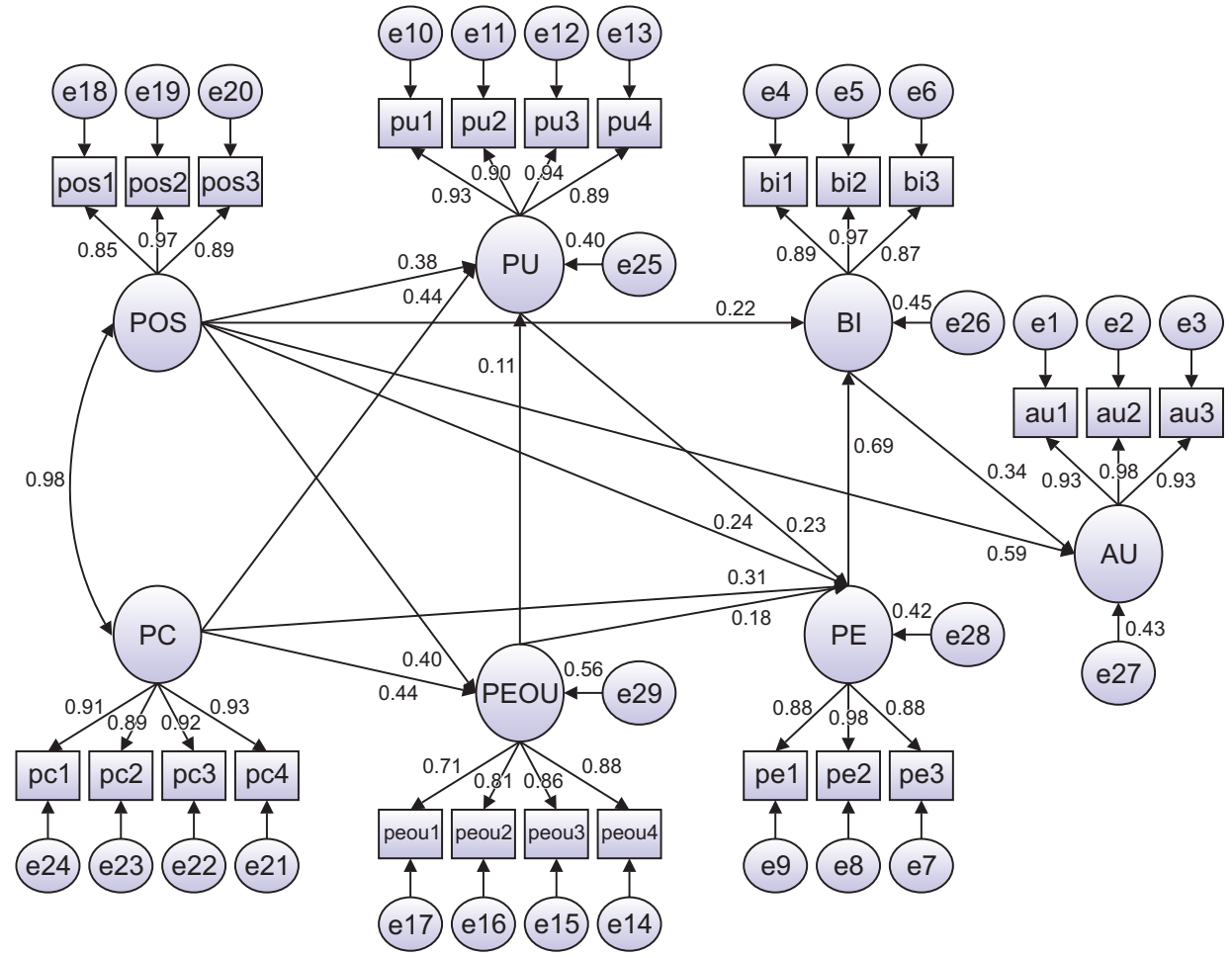

Figure 2. Final model based on structural equation modeling. POS: perceived organizational support, PC: personal characteristics, PEOU: perceived ease of use, PU: perceived usefulness, PE: perceived enjoyment, $\mathrm{BI}$ : behavioral intention to use, AU: actual system use.
Table 2. Standardized regression weights

\begin{tabular}{rlc}
\hline No. & \multicolumn{1}{c}{ Path } & Regression weights \\
\hline 1 & POS $\rightarrow$ PEOU & 0.399 \\
2 & PC $\rightarrow$ PEOU & 0.436 \\
3 & POS $\rightarrow$ PU & 0.385 \\
4 & PC $\rightarrow$ PU & 0.443 \\
5 & PEOU $\rightarrow$ PU & 0.108 \\
6 & POS $\rightarrow$ PE & 0.238 \\
7 & PC $\rightarrow$ PE & 0.309 \\
8 & PEOU $\rightarrow$ PE & 0.176 \\
9 & PU $\rightarrow$ PE & 0.227 \\
10 & POS $\rightarrow$ BI & 0.223 \\
11 & PE $\rightarrow$ BI & 0.691 \\
12 & POS $\rightarrow$ AU & 0.593 \\
13 & BI $\rightarrow$ AU & 0.344 \\
\hline
\end{tabular}

POS: perceived organizational support, PC: personal characteristics, PEOU: perceived ease of use, PU: perceived usefulness, PE: perceived enjoyment, BI: behavioral intention to use, AU: actual system use.

with a path coefficient of 0.238 ; personal characteristics, with a path coefficient of 0.118 ; perceived usefulness, with a path coefficient of 0.054; and perceived ease of use, with a path coefficient of 0.048 . The AMoMHIS is presented in Figure 3.

\section{Discussion}

In the AMoMHIS, based on the total effect, perceived organizational support had the greatest influence on actual system use, both through direct and indirect effects; thus, perceived organizational support was found to be the main determinant of MCH Information System acceptance. In fact, perceived organizational support has a stronger effect than behavioral intention on actual system use. This finding is unlike those of other information system acceptance models, which found that behavioral intention was the main determinant of actual system use [5-7,9-13]. Based on the above-mentioned results of the research, it can be understood that the use of the MCH Information System by midwives is not only based on their inner intention, but rather is more strongly influenced by external factors, namely organizational support given to them. Therefore, organizational support should receive special attention in order to increase the acceptance of the MCH Information System by users. Organizational support is complex, encompassing both material and immaterial support.

The essence of organizational support is care from the organization. Organizational concern for employees will stimulate employees to dedicate themselves to their organization. In other words, if an organization has a commitment to or cares about its employees, then employees will also show commitment to their organization [8]. In relation to the 
Table 3. Path coefficients of direct effects, indirect effects, and total effects

\begin{tabular}{|c|c|c|c|c|}
\hline No. & Path & Direct effects & Indirect effects & Total effects \\
\hline 1 & $\mathrm{POS} \rightarrow \mathrm{PEOU}$ & 0.399 & - & 0.399 \\
\hline 2 & $\mathrm{PC} \rightarrow \mathrm{PEOU}$ & 0.436 & - & 0.436 \\
\hline 3 & $\mathrm{POS} \rightarrow \mathrm{PU}$ & 0.385 & $0.043(\mathrm{POS} \rightarrow \mathrm{PEOU} \rightarrow \mathrm{PU})$ & 0.428 \\
\hline 4 & $\mathrm{PC} \rightarrow \mathrm{PU}$ & 0.443 & $0.047(\mathrm{PC} \rightarrow \mathrm{PEOU} \rightarrow \mathrm{PU})$ & 0.490 \\
\hline 5 & $\mathrm{PEOU} \rightarrow \mathrm{PU}$ & 0.108 & - & 0.108 \\
\hline 6 & $\mathrm{POS} \rightarrow \mathrm{PE}$ & 0.238 & $\begin{array}{l}0.070(\mathrm{POS} \rightarrow \mathrm{PEOU} \rightarrow \mathrm{PE}) \\
0.010(\mathrm{POS} \rightarrow \mathrm{PEOU} \rightarrow \mathrm{PU} \rightarrow \mathrm{PE}) \\
0.087(\mathrm{POS} \rightarrow \mathrm{PU} \rightarrow \mathrm{PE}) \\
0.167 \text { (total of indirect effects) }\end{array}$ & 0.405 \\
\hline 7 & $\mathrm{PC} \rightarrow \mathrm{PE}$ & 0.309 & $\begin{array}{l}0.077(\mathrm{PC} \rightarrow \mathrm{PEOU} \rightarrow \mathrm{PE}) \\
0.011(\mathrm{PC} \rightarrow \mathrm{PEOU} \rightarrow \mathrm{PU} \rightarrow \mathrm{PE}) \\
0.101(\mathrm{PC} \rightarrow \mathrm{PU} \rightarrow \mathrm{PE}) \\
0.188 \text { (total of indirect effects) }\end{array}$ & 0.497 \\
\hline 8 & $\mathrm{PEOU} \rightarrow \mathrm{PE}$ & 0.176 & $0.025(\mathrm{PEOU} \rightarrow \mathrm{PU} \rightarrow \mathrm{PE})$ & 0.200 \\
\hline 9 & $\mathrm{PU} \rightarrow \mathrm{PE}$ & 0.227 & - & 0.227 \\
\hline 10 & $\mathrm{POS} \rightarrow \mathrm{BI}$ & 0.223 & $\begin{array}{l}0.007(\mathrm{POS} \rightarrow \mathrm{PEOU} \rightarrow \mathrm{PU} \rightarrow \mathrm{PE} \rightarrow \mathrm{BI}) \\
0.049(\mathrm{POS} \rightarrow \mathrm{PEOU} \rightarrow \mathrm{PE} \rightarrow \mathrm{BI}) \\
0.060(\mathrm{POS} \rightarrow \mathrm{PU} \rightarrow \mathrm{PE} \rightarrow \mathrm{BI}) \\
0.164(\mathrm{POS} \rightarrow \mathrm{PE} \rightarrow \mathrm{BI}) \\
0.280 \text { (total of indirect effects) }\end{array}$ & 0.503 \\
\hline 11 & $\mathrm{PC} \rightarrow \mathrm{BI}$ & - & $\begin{array}{l}0.007(\mathrm{PC} \rightarrow \mathrm{PEOU} \rightarrow \mathrm{PU} \rightarrow \mathrm{PE} \rightarrow \mathrm{BI}) \\
0.053(\mathrm{PC} \rightarrow \mathrm{PEOU} \rightarrow \mathrm{PE} \rightarrow \mathrm{BI}) \\
0.069(\mathrm{PC} \rightarrow \mathrm{PU} \rightarrow \mathrm{PE} \rightarrow \mathrm{BI}) \\
0.214(\mathrm{PC} \rightarrow \mathrm{PE} \rightarrow \mathrm{BI}) \\
0.343 \text { (total of indirect effects) }\end{array}$ & 0.343 \\
\hline 12 & $\mathrm{PEOU} \rightarrow \mathrm{BI}$ & - & $\begin{array}{l}0.017(\mathrm{PEOU} \rightarrow \mathrm{PU} \rightarrow \mathrm{PE} \rightarrow \mathrm{BI}) \\
0.122(\mathrm{PEOU} \rightarrow \mathrm{PE} \rightarrow \mathrm{BI}) \\
0.138 \text { (total of indirect effects) }\end{array}$ & 0.138 \\
\hline 13 & $\mathrm{PU} \rightarrow \mathrm{BI}$ & - & $0.157(\mathrm{PU} \rightarrow \mathrm{PE} \rightarrow \mathrm{BI})$ & 0.157 \\
\hline 14 & $\mathrm{PE} \rightarrow \mathrm{BI}$ & 0.691 & - & 0.691 \\
\hline 15 & $\mathrm{POS} \rightarrow \mathrm{AU}$ & 0.593 & $\begin{array}{l}0.002(\mathrm{POS} \rightarrow \mathrm{PEOU} \rightarrow \mathrm{PU} \rightarrow \mathrm{PE} \rightarrow \mathrm{BI} \rightarrow \mathrm{AU}) \\
0.017(\mathrm{POS} \rightarrow \mathrm{PEOU} \rightarrow \mathrm{PE} \rightarrow \mathrm{BI} \rightarrow \mathrm{AU}) \\
0.021(\mathrm{POS} \rightarrow \mathrm{PU} \rightarrow \mathrm{PE} \rightarrow \mathrm{BI} \rightarrow \mathrm{AU}) \\
0.057(\mathrm{POS} \rightarrow \mathrm{PE} \rightarrow \mathrm{BI} \rightarrow \mathrm{AU}) \\
0.077(\mathrm{POS} \rightarrow \mathrm{BI} \rightarrow \mathrm{AU}) \\
0.173 \text { (total of indirect effects) }\end{array}$ & 0.766 \\
\hline 16 & $\mathrm{PC} \rightarrow \mathrm{AU}$ & - & $\begin{array}{l}0.003(\mathrm{PC} \rightarrow \mathrm{PEOU} \rightarrow \mathrm{PU} \rightarrow \mathrm{PE} \rightarrow \mathrm{BI} \rightarrow \mathrm{AU}) \\
0.018(\mathrm{PC} \rightarrow \mathrm{PEOU} \rightarrow \mathrm{PE} \rightarrow \mathrm{BI} \rightarrow \mathrm{AU}) \\
0.024(\mathrm{PC} \rightarrow \mathrm{PU} \rightarrow \mathrm{PE} \rightarrow \mathrm{BI} \rightarrow \mathrm{AU}) \\
0.073(\mathrm{PC} \rightarrow \mathrm{PE} \rightarrow \mathrm{BI} \rightarrow \mathrm{AU}) \\
0.118 \text { (total of indirect effects) }\end{array}$ & 0.118 \\
\hline 17 & $\mathrm{PEOU} \rightarrow \mathrm{AU}$ & - & $\begin{array}{l}0.006(\mathrm{PEOU} \rightarrow \mathrm{PU} \rightarrow \mathrm{PE} \rightarrow \mathrm{BI} \rightarrow \mathrm{AU}) \\
0.042(\mathrm{PEOU} \rightarrow \mathrm{PE} \rightarrow \mathrm{BI} \rightarrow \mathrm{AU}) \\
0.048 \text { (total of indirect effects) }\end{array}$ & 0.048 \\
\hline
\end{tabular}


Table 3. Continued

\begin{tabular}{ccccc}
\hline No. & Path & Direct effects & Indirect effects & Total effects \\
\hline 18 & $\mathrm{PU} \rightarrow \mathrm{AU}$ & - & $0.054(\mathrm{PU} \rightarrow \mathrm{PE} \rightarrow \mathrm{BI} \rightarrow \mathrm{AU})$ & 0.054 \\
19 & $\mathrm{PE} \rightarrow \mathrm{AU}$ & - & $0.238(\mathrm{PE} \rightarrow \mathrm{BI} \rightarrow \mathrm{AU})$ & 0.238 \\
20 & $\mathrm{BI} \rightarrow \mathrm{AU}$ & 0.344 & - & 0.344 \\
\hline
\end{tabular}

POS: perceived organizational support, PC: personal characteristics, PEOU: perceived ease of use, PU: perceived usefulness, PE: perceived enjoyment, $\mathrm{BI}$ : behavioral intention to use, $\mathrm{AU}$ : actual system use.

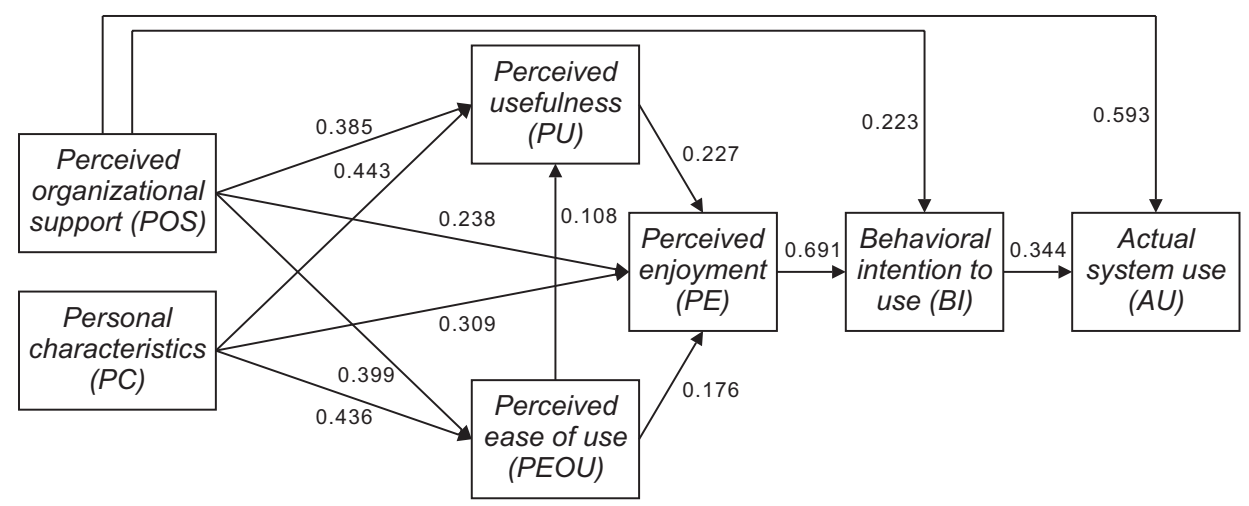

Figure 3. Acceptance model of the Maternal and Child Health Information System in Ngawi Regency, Indonesia. implementation of technology-based information systems, organizational care can be given in the form of supervisor support, work conditions, and rewards [3].

Supervisor support in the implementation of the $\mathrm{MCH}$ Information System refers to the encouragement given by direct superiors and information system managers [3]. The study results show that users still felt that support from supervisors was low in the implementation of the $\mathrm{MCH}$ Information System in the Ngawi Regency Health Office. This should be of serious concern to direct supervisors and system administrators. Active assistance and supervision will condition users to always actively implement information systems (actual system use). In other words, mentoring and supervision of superiors will condition village midwives not to delay the implementation of the system, to operate the system regularly, and to maintain the sustainable use of the MCH Information System.

Work conditions are also a form of organizational support, and include a good communication climate, the existence of a help desk, and the availability of supporting resources [3]. The results of the study show that users still felt that the level of support in terms of their work conditions was low for the implementation of the $\mathrm{MCH}$ information system in the Ngawi Regency Health Office, so this should also receive serious attention. A good communication climate between users and between users and supervisors will open up opportunities for them to help each other, making use of the system easier. A help desk that is always ready at any time will facilitate solving problems encountered by users while running the $\mathrm{MCH}$ Information System. Meanwhile, the availability of supporting resources such as facilities and infrastructure will also make it easier for users to use the system. Work conditions affect the perceived ease of use or the level of ease felt by users in operating the $\mathrm{MCH}$ Information System. Furthermore, sequentially, ease of use affects perceived enjoyment, behavioral intention, and actual system use.

Meanwhile, rewards can act as a stimulus for village midwives as users to be more active in operating the MCH Information System. The results of the study indicate that in general, the rewards given in relation to additional tasks as users of the MCH Information System in the Ngawi Regency Health Office are still low. Awards can be financial and nonfinancial rewards. Financial rewards can be in the form of incentives, while non-financial rewards can be in the form of increased self-esteem, feelings of achievement, and feelings of development [3]. If the village midwives feel valued both financially and non-financially, they will be motivated to implement the MCH Information System (actual system use).

The factor with the second strongest influence on actual system use was behavioral intention to use. In previous research, behavioral intention to use has been found to be the main direct determinant of actual system use. In general, TAM analyses to date still involve behavioral intention to use as a direct determinant of actual system use, including the 
developments of TAM into TAM-2 and TAM-3 [5-7]. Referring to the results of this study, it is expected that in the implementation of the MCH Information System in particular and information systems within an organization in general, efforts should always be made to foster users' intention to run the information system voluntarily, so that they can be convinced of the sustainable implementation of the information system [3,5].

Referring to the results of this study, in addition to organizational support, the intention or "voluntary will" of the village midwives should also be a major concern in efforts to increase the acceptance of the MCH Information System. However, the intention of village midwives to run the $\mathrm{MCH}$ Information System in the Ngawi Regency Health Office is still low. Therefore, policy-makers must make various efforts to promote voluntary willingness among village midwives as users, for example through development efforts, characterbuilding, and fostering organizational citizenship behavior.

The factor with the third strongest influence on actual system use was perceived enjoyment. Referring to the results of this study and previous research by Nugroho et al. [3], efforts should be made in the implementation of the $\mathrm{MCH}$ Information System in particular and in mandatory information systems in general, for users to enjoy the use of the system, which is characterized by passion, pleasure and adaptability when operating an information system. Perceived enjoyment has been proven to act as an intervening variable in the indirect effect path of perceived organizational support and personal characteristics on actual system use. It can be said that perceived enjoyment is the main intermediary, because of the effects of perceived ease of use and perceived usefulness on behavioral intention to use, which in turn affects actual system use; these effects must all go through perceived enjoyment. Furthermore, perceived enjoyment is also the only connecting pathway for the influence of perceived organizational support, personal characteristics, perceived ease of use, and perceived usefulness on behavioral intention to use, which in turn affects actual system use. Without going through perceived enjoyment, the path of perceived ease of use and accelerated usefulness is broken in the middle, because the direct influence of these two variables on behavioral intention to use is too weak to be meaningful.

In this case, the village midwives in the Ngawi Regency Health Office still felt that their enjoyment was low when running the $\mathrm{MCH}$ Information System. In accordance with the results of the analysis, enjoyment can be fostered by increased organizational support and modifiable personal characteristics, such as education and training, experience using computers, ease of use of the system, and the perceived usefulness of the information system implemented.

In the AMoMHIS, personal characteristics (years of service, age, education, training, and experience using a computer) were shown to act as external variables that influenced actual system use through indirect effects. Based on the value of the path coefficient (regression weight), this effect was weak, so it can be said that personal characteristics are not the main determinant of the acceptance of the MCH Information System. In the first path, personal characteristics influenced the perceived ease of use, perceived usefulness, and perceived enjoyment. Furthermore, perceived enjoyment successively influenced behavioral intention to use and actual system use. An individual's working period and age are factors that cannot be modified, but it should be noted that if the working environment is conducive, then an increased working period and age will increase employees' exposure to the conducive situation, especially an enabling situation in which village midwives become more familiar with and understand the information system. Thus, they will find it easier to use the MCH Information System (perceived ease of use). An increasing working period and age will also increase the duration and frequency of access to the $\mathrm{MCH}$ Information System, thereby increasing the opportunity for village midwives to become more familiar with the $\mathrm{MCH}$ Information System. This familiarity will make village midwives more likely to know and feel familiar with the functions of the $\mathrm{MCH}$ Information System in supporting the completion of their daily work (perceived usefulness), especially regarding the implementation of the MCH Program.

This chain of reasoning aligns with the statement of $\mathrm{Da}$ vis et al. [5] that the implementation of technology-based information systems can provide many benefits, such as increasing the quality of work, accelerating work completion, increasing the volume of work completed, and completing critical aspects of work. An increasing working period and age will also provide more opportunities for village midwives to have positive experiences such as adjustment, problemsolving, goal achievement, and self-development, which will make it easier for them to reach emotional maturity. In turn, emotional maturity can create a positive mood and increase the ability to adapt to stressors [3] (in this case, the MCH Information System can be a stressor for village midwives), so that in turn, midwives will find enjoyment in operating the information system (perceived enjoyment).

In contrast, education level, training experience, and computer experience are modifiable factors; which means that if education, training, and activities using computers can be 
improved, individuals will gain practice with repeated computer use. Repeated use will make village midwives more familiar with information technology, so that they will have more learning experiences, which in turn will make them feel more proficient at using the MCH Information System (perceived ease of use). The level of education, training experience, and experience using computers also provide opportunities for village midwives to become more familiar with the benefits of information technology in general (perceived usefulness), especially the benefits of supporting the completion of daily tasks [3,5]. Training and experience using computers can also help village midwives to become more familiar with computers, fostering a sense of excitement and enthusiasm for operating the $\mathrm{MCH}$ Information System, which will promote perceived enjoyment [3].

Based on the description above, two novel findings can be highlighted: (1) perceived organizational support was the main determinant of actual system use; and (2) perceived enjoyment was the main intermediate factor responsible for the indirect effects of perceived organizational support and personal characteristics on actual system use. The $\mathrm{MCH}$ Information System as the object of this study is one an example of an information system in an organization; thus, although the conclusions of this study specifically apply only to the reception of the MCH Information System in the Ngawi Regency Health Office, this model can be used as a reference to explain the acceptance of information systems in organizations in general, which must be verified through further research.

There are several limitations in this study. First, this research only focused on the acceptance of the MCH Information System, so it cannot be generalized to all health information systems, or for other types of information systems. Second, the organizational factors involved in developing the model are still limited to perceived organizational support, and do not yet involve other organizational factors such as organizational commitment or organizational justice. Third, the personal factors involved in developing the model were limited to personal characteristics, and did not involve other personal factors such as intrinsic motivation, involvement, or personality. Fourth, the psychological factors involved in the development of the model were limited to perceived enjoyment, without involving other emotional factors such as awareness, anxiety using the computer, trust, or volunteerism.

Based on the findings and identified limitations, a future work plan has been prepared, namely:

1) Developing acceptance models for various information systems, especially mandatory information systems, to deepen and expand the theoretical background of the information system acceptance model

2) In order to increase the acceptance of the $\mathrm{MCH}$ Information System in the Ngawi Regency Health Office, the following improvements are proposed:

a) Organizational support must be prioritized, especially supervisor support, a conducive work environment, and rewards for operators,

b) Increased training and mentoring should be provided during system implementation, so that users are always familiar with the MCH Information System,

c) The offline system should be changed to an online system that can be accessed via computers or mobile devices, so that the system will become more flexible, simple, and easy to learn.

d) The content should be adjusted to fit the main duties of the village midwife, making it more useful to support the completion of daily tasks.

e) The system should be equipped with features that can increase comfort in using the system, such as attractive visuals and audio/music provision;

3) The Head of the Ngawi Regency Health Office and heads of community health centers will be encouraged to propose a model for the acceptance of the MCH Information System as a pilot model to a higher level, namely the East Java Provincial Health Office.

4) The relevance of the AMoMHIS will be tested as a model that can explain the acceptance of various information systems in organizations, through further research on information systems in other organizations.

In conclusion, the AMoMHIS developed herein involves perceived organizational support, personal characteristics, perceived enjoyment, perceived ease of use, perceived usefulness, behavioral intention to use, and actual system use; with perceived organizational support as the main determinant and perceived enjoyment as a major intermediary factor.

As noted above, the MCH Information System is a mandatory information system, which requires users to operate it. Therefore, the AMoMHIS can be used to explain user acceptance of the mandatory health information systems.

\section{Conflict of Interest}

No potential conflict of interest relevant to this article was reported. 


\section{Acknowledgments}

Thank and highest appreciation goes to the Director of the Poltekkes Kemenkes Surabaya, the Dean of the Faculty of Public Health, Airlangga University and the Head of the Ngawi Regency Health Office who have supported this research.

\section{ORCID}

Heru Santoso Wahito Nugroho (https://orcid.org/0000-0002-4511-8307) Hari Basuki Notobroto (https://orcid.org/0000-0002-3905-7413) Lilin Rosyanti (https://orcid.org/0000-0003-3610-1017)

\section{References}

1. Ministry of Health of the Republic of Indonesia. Guidelines for Local Area Monitoring for Maternal and Child Health [Pedoman Pemantauan Wilayah Setempat Kesehatan Ibu dan Anak (PWS-KIA)] [Internet]. Jakarta, Indonesia: Ministry of Health of the Republic of Indonesia; 2010 [cited at 2021 Apr 29]. Available from: http:// dinkes.sumutprov.go.id/common/upload/Pedoman $\% 20$ PWS\%20KIA\%20kemenkes\%202010.pdf.

2. FKM-UNSRAT Teaching Team. Health information systems lecture module: basic concepts and application of health information systems [Konsep dasar dan penerapan sistem informasi kesehatan] [Internet]. Manado, Indonesia: UNSRAT Faculty of Public Health; 2017 [cited at 2021 Apr 29]. Available from: https://inspire. unsrat.ac.id/uploads/daring/berkas/2017-07-17berkas1979112520090320016.pdf.

3. Nugroho HS, Supriyanto S, Notobroto HB. The role of perceived organizational support, personal characteristic and perceived enjoyment in acceptance model of maternal and child health information system [Peran perceived organizational support, personal characteristic, dan perceived enjoyment dalam model penerimaan sistem informasi kesehatan ibu dan anak]. Surabaya,
Indonesia: Airlangga University; 2016.

4. Ngawi Regency Health Office. Results of supervision of the implementation of the health information system at the Ngawi Regency Health Office [Hasil supervisi pelaksanaan sistem informasi kesehatan di dinas kesehatan kabupaten Ngawi]. Ngawi, Indonesia: Ngawi Regency Health Office; 2014.

5. Davis FD, Bagozzi RP, Warshaw PR. User acceptance of computer technology: a comparison of two theoretical models. Manag Sci 1989;35(8):982-1003.

6. Venkatesh V, Davis FD. A theoretical extension of the technology acceptance model: four longitudinal field studies. Manag Sci 2000;46(2):186-204.

7. Venkatesh V, Bala H. Technology acceptance model 3 and a research agenda on interventions. Decis Sci 2008; 39(2):273-315.

8. Kurtessis JN, Eisenberger R, Ford MT, Buffardi LC, Stewart KA, Adis CS. Perceived organizational support: A meta-analytic evaluation of organizational support theory. J Manag 2017;43(6):1854-84.

9. Indipenrian BN, Subroto B, Rahman AF. Analysis of behavioral intention on $\mathrm{ABC}$ system adoption: model of information systems technology and success acceptance. J Econ Bus Account Ventura 2015;18(3):403-16.

10. Berry AM. Behavioral intention and use behavior of social networking websites among senior adults [dissertation]. Fort Lauderdale (FL): Nova Southeastern University; 2017.

11. Uska MZ. Analisis Penerimaan Digital Library Menggunakan Technology Acceptance Model (TAM) di Universitas Hamzanwadi. Edumatic: Jurnal Pendidikan Informatika 2017;1(1):1-10.

12. Gomer S, Hasyim, Kusumapradja R. Acceptance model of hospital information management system: case of study in Indonesia. Eur J Bus Manag Res 2020;5(5):505.

13. Komalasari F, Ramadhani F. The change of banking culture: factors affecting online banking usage in Indonesia. J Sampurasun: Interdiscip Stud Cult Herit 2020;6(2): 45-58. 